REGARDS

SUR LECONOMIE ALLEMANDE

BULLETIN ECONOMIQUE DU CIRAC

\section{Regards sur l'économie allemande}

Bulletin économique du CIRAC

$67 \mid 2004$

Varia

\title{
[20. Ordolibéralisme
}

EVERS Marc, Die institutionelle Ausgestaltung von

Wirtschaftsordnungen

\section{(2) OpenEdition}

\section{Journals}

Édition électronique

URL : http://journals.openedition.org/rea/3831

DOI : $10.4000 /$ rea.3831

ISBN : 978-2-8218-0830-0

ISSN : 1965-0787

Éditeur

CIRAC

Édition imprimée

Date de publication : 1 juillet 2004

ISSN : 1156-8992

Référence électronique

《㡠 Ordolibéralisme», Regards sur l'économie allemande [En ligne], 67 | juillet 2004, mis en ligne le 08 octobre 2009, consulté le 22 septembre 2020. URL : http://journals.openedition.org/rea/3831 ; DOI : https://doi.org/10.4000/rea.3831

Ce document a été généré automatiquement le 22 septembre 2020.

(c) CIRAC 


\section{医 Ordolibéralisme}

EVERS Marc, Die institutionelle Ausgestaltung von

Wirtschaftsordnungen

\section{RÉFÉRENCE}

EVERS Marc, Die institutionelle Ausgestaltung von Wirtschaftsordnungen, Coll. Schriften zur wirtschaftswissenschaftlichen Analyse des Rechts, vol. 47, Duncker \& Humblot, Berlin, 2003, 336 p.

1 La globalisation ne rend pas obsolète l'approche du libéralisme organisé. Car l'ordolibéralisme, tel qu'il s'est développé outre-Rhin après la guerre, est par essence évolutif: il est fondé sur l'interdépendance entre les formes nationales d'organisation du marché et le contexte dans lequel elles évoluent - à l'instar d'une organisation apprenante. (IB) 